\title{
Effect of $\alpha$-difluormethylornithine on Anastrepha fraterculus (Diptera, Tephritidae) ovary size
}

\author{
Cardoso, $V V^{\mathrm{a}, \mathrm{c}}$, Moreira, $J C F^{\mathrm{b}}$ and Oliveira, $A K^{\mathrm{a}}{ }^{\mathrm{*}}$ \\ aDepartamento de Genética, Instituto de Biociências, \\ Universidade Federal do Rio Grande do Sul - UFRGS \\ Av. Bento Gonçalves, 9500, Agronomia, CEP 91501-970, Porto Alegre, RS, Brazil

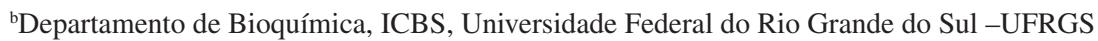 \\ Porto Alegre, RS, Brazil \\ ${ }^{\mathrm{c}}$ Centro Universitário Metodista do IPA, \\ Porto Alegre, RS, Brazil \\ *e-mail: anastrefa@ig.com.br
}

Received April 16, 2007 - Accepted October 3, 2007 - Distributed February 28, 2009

(With 2 figures)

\begin{abstract}
Ovarian sizes (length and width) were measured in young females of Anastrepha fraterculus (Wiedemann) (Diptera, Tephritidae) subjected or not to the inhibitor $\alpha$-difluormethylornithine ( $\alpha$-DFMO). The most effective concentration of $\alpha$-DMFO used was $50 \mathrm{mM}$ and the ovarian measurements (length and width) of the treated females were smaller than those of females not treated with $\alpha$-DMFO. These data may suggest some relationship between ornithine decarboxylase (ODC) and sexual maturation in A. fraterculus.
\end{abstract}

Keywords: Anastrepha fraterculus, $\alpha$-difluormethylornithine, ovarian size .

\section{Efeito da $\alpha$-difluorometilornitina nas dimensões dos ovários em Anastrepha fraterculus (Diptera, Tephritidae)}

\begin{abstract}
Resumo
As dimensões dos ovários (comprimento e largura) foram mensuradas em fêmeas jovens da Anastrepha fraterculus (Wiedemann) (Diptera, Tephritidae) submetidas ou não ao inibidor $\alpha$-difluormetilornitina ( $\alpha$-DFMO). A concentração mais efetiva de $\alpha$-DMFO utilizada foi $50 \mathrm{mM}$ e as medidas (comprimento e largura) das fêmeas tratadas com o inibidor foram menores que as fêmeas não tratadas com inibidor $\alpha$-DMFO. Estes dados podem sugerir uma relação entre ornitina descarboxilase (ODC) e maturação sexual em A. fraterculus.
\end{abstract}

Palavras-chave: Anastrepha fraterulus, $\alpha$-difluoro metil ornitina; tamanho do ovário.

\section{Introduction}

Vitellogenesis is a major component of insect oogenesis. Vitellogenesis comprises the synthesis of the yolk protein precursor vitellogenin in body fat, its secretion into the hemolymph, and its transportation to the follicles, where they are selectively bound and internalized into oocytes as vitellin (Hagedorn and Kunkel, 1979). Almost all insects follow this paradigm. However, in many higher diptera, the ovarian follicular epithelium also provides a source for the same proteins (Jowet and Postlethwait, 1980). In Drosophila the JH is thought to be secreted shortly after eclosion and acts in some way to initiate vitellogenin synthesis in both the body fat and ovaries, as well as the ovarian uptake of vitellogenin syn- thesis from hemolymph (Postlethwait and Shirk, 1981; Bownes, 1982, 1986).

Many studies have shown that ornithine decarboxylase (ODC; EC 4.1.1.17) activity is needed for insect vitellogenesis and sexual maturation (Birnbaum and Gilbert, 1990; Cardoso et al., 2004; Cardoso et al., 2006). ODC is very important for polyamine biosynthesis (Tabor and Tabor, 1984). Polyamines are aliphatic cations involved in the control of growth and are required for a wide variety of biological events such as protein synthesis, DNA replication and cell division. Studies of the metabolism during embryonic development of vertebrate and invertebrate have indicated that polyamines 
can be very important for a good development process. The changes in ODC activity and polyamine synthesis have been followed in Manduca sexta (Birnbaum and Whelan, 1988), Tenebrio molitor (Besson et al., 1986), Hyalophora cecropia (Wyatt et al., 1973), Drosophila melanogaster (Birnbaum and Gilbert, 1990), and Aedes aegypti (Kogan and Hagerdorn, 2000). Moreover, some studies have associated normal vitellogenesis with ODC activity, which in Drosophila reaches a peak at 24 hours following adult eclosion and is reduced at 48 hours. This pattern is not observed in males. So, it is suggested that polyamine synthesis is involved in ovarian maturation (Birnbaum and Gilbert, 1990).

The $\alpha$-difluormethylornithine ( $\alpha$-DFMO), which is the ornithine decarboxylase suicide inhibitor, has been extensively used to study the effects of limiting polyamine synthesis in cell culture and in experimental animals (Pöso and Pegg, 1982; Pegg, 1986; Grossie et al., 1987; Kogan and Hagedorn, 2000).

Inhibition of polyamine synthesis will help our understanding of the role of these ubiquitous molecules during insect growth processes. In the present study, we observed ovarian size (length and width) in young females of Anastrepha fraterculus Wiedemann) (Diptera, Tephritidae) treated or not with the inhibitor $\alpha$-DFMO A. fraterculus is one of about 195 species of the Anastrepha genus. This fly is distributed in Continental America and is considered one of the most important fruit culture pests.

\section{Materials and Methods}

\subsection{Animals}

Infested fruits (Campomanesia xanthocarpa Berg.) were collected in the town of São Joaquim (SC-Brazil) and kept under laboratory conditions at $25^{\circ} \mathrm{C} \pm 1{ }^{\circ} \mathrm{C}, \mathrm{L}: \mathrm{D}$ of 12:12 cycle, and 60-80 RH. After adult eclosion, the F1 was distributed into plastic cages $(19 \times 13 \times 13 \mathrm{~cm})$ and provided with food (brown sugar:soy bean flour:wheat flour $3: 1: 1)$ and water.

\subsection{Chemicals}

$\alpha$-difluormethylornithine ( $\alpha$-DMFO) was purchased from Sigma.

\section{3. $\alpha$-DMFO dose curve}

Just after emergence, groups of 5 females were supplied with $\alpha$-DMFO in increasing concentrations $(5,15$, 20,30 and $50 \mathrm{mM}$ ) as drinking water solution placed in cotton square pieces, and the other 5 female groups (control) did not receive $\alpha$-DMFO. During 4 days the treatments were daily renewed. Then, on the fourth day, the ovaries were dissected in physiological Ephrussi solution and the ovaries measured (length and width) under a Leica microscope (x5) coupled to a computer using a software called Somniun, an application for data processing developed in Interactive Data Language (IDL) by the Laboratory of Vegetable Anatomy at the
Federal University of Rio Grande do Sul, Brazil. IDL is a complete computing environment for the interactive analysis and visualization of data.

\section{4. $\alpha$-DMFO treatment}

Just after emergence, a group of females was supplied with $\alpha$-DMFO (50 mM) in the drinking solution, and another female group (control) did not receive $\alpha$-DMFO. During 4 days, the treatment was daily renewed. Then, on the fourth day, fifteen females treated and 15 females not treated with $\alpha$-DMFO were dissected in physiological Ephrussi solution and the ovaries measured (length and width).

\subsection{Statistical analysis}

The effect of the different doses of $\alpha$-DMFO on young A. fraterculus ovary measurements was analyzed by non-parametric Kruskal-Wallis statistical analysis following Tukey's HSD (multiple comparison) post hoc test $(\mathrm{p}<0.05)$.

The influence of $\alpha$-DMFO $(50 \mathrm{mM})$ treatment on young $A$. fraterculus ovary measurements was analyzed by the $t$-test for independent samples and $\mathrm{p}<0.05$.

\section{Results}

As can be seen in Figure 1 the most effective concentration of $\alpha$-DMFO used was $50 \mathrm{mM}$. The other concentrations $(5,15$ and $30 \mathrm{mM})$ didn't show differences in ovary size (length and width) when compared to the untreated control groups.

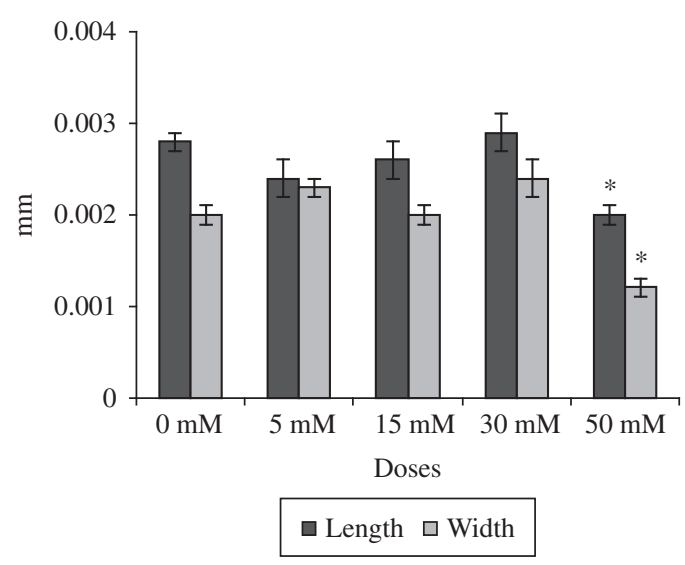

Figure 1. Different concentrations (0, 5, 15, 30 and $50 \mathrm{mM})$ of $\alpha$-DMFO used to measure the length and width in ovaries of $A$. fraterculus females (4 days old). Measurements were assessed as described in Materials and Methods; each histograph bar represents mean and standard error ( \pm se), $\mathrm{n}=5$ different animals. Asterisk indicates statistical difference by non-parametric Kruskal-Wallis statistical analysis following Tukey's HSD (multiple comparison) post hoc test $(\mathrm{p}<0.05)$. 
The measurements (length and width) of 15 females treated with $\alpha$-DMFO $(50 \mathrm{mM})$ showed significant differences with the females not treated with $\alpha$ - DMFO.

\section{Discussion}

Specific cellular changes that are needed for development, differentiation of cell type, and tissue reprogramming require polyamines. Moreover, massive RNA synthesis, necessary for embryogenesis, is blocked if ODC and polyamines are lacking (Heby and Emanuelsson, 1981; Frydman et al., 1992). Polyamines are important in embryonic development as evidenced by early sea urchin eggs (Kusunoki and Yamasu, 1978). Administration of $\alpha$-DMFO to neonate rats results in brain polyamine depletion, brain growth deficit together with a retardation of synaptic development (Slotkin et al., 1984). However, despite the increasing evidence of the importance of polyamines for the cellular process, until now, few studies have focused on the role of ODC and polyamines in insect development.

The ODC suicide inhibitor $\alpha$-DMFO has been used in studies of the roles of ODC and polyamines at the biochemical and physiological levels (Bitonti et al., 1985; Pegg, 1986). It was observed that it reduces the risk of cancer in animals. This inhibitor was also used as a plant fungicide and it showed protective role because it inhibits fungal pathogenic effects on plants (Rajam et al., 1985).

In the present study, it was observed that in A. fraterculus young females ( \pm 4 days), $\alpha$-DMFO significantly inhibited ovary development (length and width)

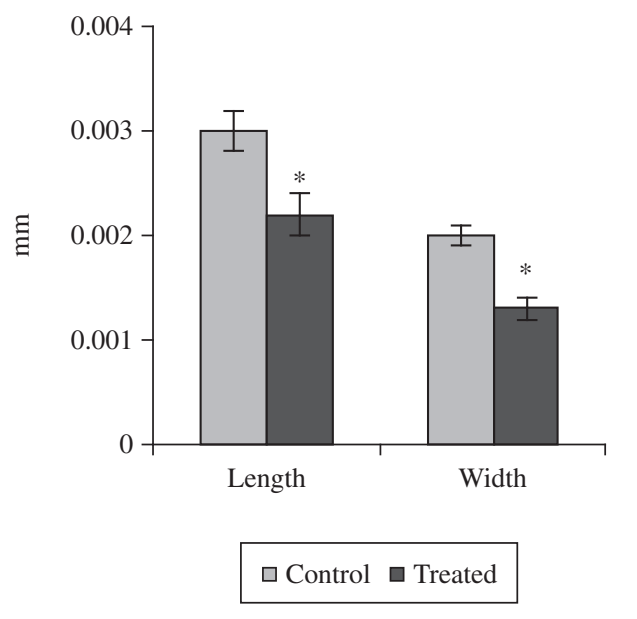

Figure 2. Effect of $\alpha$-DMFO (50 mM) treated on ovary measurements (length and width) of $A$. fraterculus young females (4 days old). Measurements were assessed as described in Materials and Methods; each histograph bar represents mean and standard error $( \pm$ se $) n=15$ different animals. Asterisk indicates statistical difference by t-test for independent samples and $\mathrm{p}<0.05$. when compared with females kept without $\alpha$-DMFO. In a previous study, we showed that $A$. fraterculus ODC activity in eggs, young ovary and body fat were significantly higher than values recorded for other fly tissues (Cardoso et al., 2004). This ODC activity pattern was suggested to have an association with the process of oogenesis and vitellogenesis in immature females (Cardoso et al., 2004). The results in the present study corroborate the suggestion that ODC and polyamines are associated with sexual maturation in females of A. fraterculus.

Many studies correlate high levels of polyamines to the beginning of vitellogenin synthesis (Hagedorn and Kunkel (1979); Racioppi et al., 1986). Kogan and Hagerdorn, (2000) suggested that ODC and polyamines are important for normal vitellogenesis in the mosquito Aedes aegypti. They observed that the inhibitor of ODC reduced significantly the number of mature oocytes. Cayre et al. (1996), using Acheta domesticus females, observed that $\alpha$-DMFO treated ovarian development was similar to untreated control females. However some drug-treated females, having reduced ovaries, were discarded and were not used in the course of the study. Moreover the treatment with the inhibitor altered the time between emergence and egg-laying behavior appearance.

Although it would be premature to hypothesize any causal link between sexual maturation and ODC activity, we suggest that it may be a good model for further study of the role of ODC and polyamines in the maturation of A. fraterculus.

Acknowledgements - We are grateful to Dr. Bacchi C.J. (Pace University, Haskins labs, New York) for fellowships.

\section{References}

BESSON, MT., DELBECQUE, J., MATHELIN, J., and BOISSON, AM., 1986. Epidermal polyamine levels related to cell cycle events during the metamorphosis of Tenebrio molitor L. (Insect, Coleoptera): effect of juvenoid application. Comparative Biochemistry and Physiology, vol. 83, no. 3, p. 589-593.

BIRNBAUM, MJ. and GILBERT, LI., 1990. Juvenile hormone stimulation of ornithine decarboxylase activity during vitellogenesis in Drosophila melanogaster. Journal Comparative Physiology B, vol. 160, no. 2, p. 145-151.

BIRNBAUM, MJ. and WHELAN, T., 1988. Temporal alterations of ornithine decarboxylase activity in development of Manduca sexta. Insect Biochemestry, vol. 18, no. 8, p. 853-859.

BITONTI,AJ.,BACCHI, CJ., MCCANN,PP. and SJOERDSMA, A., 1985. Catalytic irreversible inhibition of Trypanossomo brucei ornithine decarboxylase (E.C.4.1.1.17) by substrate and product analogs and effects on murine trypoasomiasis. Biochemical Pharmacology, vol. 34, no. 10, p. 1773-1778.

BOWNES, M., 1982. Hormonal and genetic regulation of vitellogenin (yolk protein). Quartely Review Biology, vol. 57, no. 3, p. 247-274. 
BOWNES, M., 1986. Expression of the genes coding for vitellogenin (yolk protein). Annual Review Entomology, vol. 31, p. 507-531.

CARDOSO, VV., PRESTES, RP., CASALI, EA., MOREIRA, JCF. and OLIVEIRA, AK., 2004. Ornithine decarboxylase activity during the development of Anastrepha fraterculus (Diptera, Tephritidae). Archives of Insect Biochemistry and Physiology, vol. 57, no. 4, p. 151-159.

CARDOSO, VV., PRESTES, RP., CASALI, EA., MOREIRA, JCF. and OLIVEIRA, AK., 2006. Changes in ornithine decarboxylase activity in response to temperature stress and stimulation of juvenile hormone in Anastrepha fraterculus (Diptera, Tephritidae). Archives of Insect Biochemistry and Physiology, vol. 62, no. 4, p. 176-185.

CAYRE, M., STRAMBI, C., CHARPIN, P., AUGIER, R., RENUCCI, M. and STRAMBI,A., 1996. Inhibition of polyamine biosynthesis alters ovoposition behavior in female crickets. Behavioral Neuroscience, vol. 110, no. 5, p. 1117-1125.

FRYDMAN, L., ROSSOMANDO, PC., FRYDMAN, V., FERNANDEZ, CO., FRYDMAN, B. and SAMEJINMA, K., 1992. Interactions between natural polyamine and tRNA: an N $\mathrm{NMr}$ analysis. Proceedings of the National Academy of Sciences of the United States of America, vol. 89, p. 9186-9190.

GROSSIE Jr, BV., OTA, DM., AJANI, JA. and NISHIHIOKA K., 1987. Effect of intravenous -difluoromethylornithine on the polyamines levels of normal tissue and a transplantable fibrosarcoma. Cancer Research., vol. 47, no. 7, p. 1836-1840.

HAGEDORN, HH., O'CONNOR, JD., FUCHS, MS., SAGE, B., SCHLAEGER, DA. and BOHM, MK., 1975. The ovary as a source of $\alpha$-ecdysone in an adult mosquito. Proceedings of the National Academy of Sciences of the United States of America, vol. 72, p. 3255-3259.

HAGEDORN, HH. and KUNKEL JG., 1979. Vitellogenin and vitellin in insects. Annual Review of Entomology, vol. 24, p. $475-505$.

HEBY, O. and EMANUELSSON, H., 1981. Role of the polyamines in germ cell differentiation and in early embryonic development. Medical Biology, vol. 59, no. 6, p. 417-422.

JOWET, T. and POSTLETHWAIT, JH., 1980. The regulation of yolk polypeptide synthesis in Drosophila ovaries and fat body 20-hidroxyecdysone and juvenile hormone analogue. Developmental Biology, vol. 80, no. 1, p. 225-234.

KOGAN, HP. and HAGEDORN, HH., 2000. Polyamines, and effects from reducing their synthesis during egg development in the yellow fever mosquito, Aedes aegypti. Journal Physiology, vol. 46, no. 5, p. 1079-1095.

KUSUNOKI, S. and YAMASU, I., 1978. Inhibitory effect of $\alpha$-hydrazinoornithine on egg cleavage in sea urchin eggs. Developmental Biology, vol. 67, no. 2, p. 36-345.

PEGG, AE., 1986. Recent advances in the biochemistry of polyamines in eukaryotes. Biochemistry Journal, vol. 234, p. 249-262.

PÖSO, H. and PEGG, AE., 1982. Effect of $\alpha$-difluoromethylornithine on polyamines and DNA synthesis by putrescina. Biochemistry Biophysis Acta, vol. 696, p. 179-186.

POSTLETHWAIT, JH. and SHIRK, PD., 1981. Genetic and Endocrine Regulation of vitellogenesis in Drosophila. American Zoologist, vol. 21, p. 687-700.

RACIOPPI, JV., GEMMILL, RM., KOGAN, PK., CALVO, JM. and HAGEDORN, HH., 1986. Expression and regulation of vitellogenin messenger RNA in the mosquito Aedes aegypti. Insect Biochemistry, vol. 16, no. 1, p. 255-262.

RAJAM, MV., WEINSTEIN, LH. and GALSTON, AW., 1985. Prevention of a plant disease by specific inhibition of fungal polyamines biosynthesis. Proceedings of the National Academy of Sciences of the United States of America, vol. 82, p. 6874-6878.

SLOTKIN, TA., JONHSON, A., WHITMORE, WL. and SLEPETIS, R.J., 1984. Ornithine decarboxylase and polyamines in developing rat brain and heart: effects of perinatal hypothyroidism. International Journal Development Neuroscience, vol. 2, no. 3, p. 155-161.

TABOR, CW. and TABOR, H., 1984. Polyamines. Annual Review of Biochemistry, vol. 53, p. 749-790.

WYATT, GR., ROTHAUS, K., LAWLER, D., and HERBST, EJ., 1973. Ornithine decarboxylase and polyamines in silkmonth pupal tissues: effects of ecdysones and injury. Biochimica et Biophysica Acta, vol. 304, no. 2, p. 482-494. 